\title{
Study protocol of a quasi-experimental trial to compare two models of home care for older people in the primary setting
}

\author{
Carolina Burgos-Díez ${ }^{1,2}$, Rosa Maria Sequera-Requero ${ }^{3}$, Francisco José Tarazona-Santabalbina ${ }^{4}$, \\ Joan Carles Contel-Segura ${ }^{5}$, Marià Monzó-Planella ${ }^{1}$ and Sebastià Josep Santaeugènia-González ${ }^{5,6^{*}}$ (D)
}

\begin{abstract}
Background: Preventive home visits are suited for patients with reduced mobility, such as older people. Healthcare needs for older patients are expected to increase due to the extended life expectancy estimated in coming years. The implementation of low-cost, patient-centered methodologies may buffer this rise in health care costs without affecting the quality of service. In order to find the best home care model with less investment, this paper describes a study protocol comparing two models of home care for older people.

Methods: We describe a quasi-experimental study that compares the outcome of two different home care models already implemented in two primary care centers in Badalona (Barcelona, Spain). The traditional model (control model) is integrated in the sense that is continuous, the same primary care center team looks after its assigned patients both at the center and in preventive home visits. The new functional home care model (study model), consisting of a highly trained team, is specifically designed to meet patient needs and give total attention to preventive home interventions. The study will start and end on the expected dates, June 2018 to October 2020, and include all patients over 65 years old already enrolled in the home care programs of the primary care centers selected. The primary endpoint assessed will be the difference in hospitalization days between patients included in both home care programs. Other variables regarding health status, quality of care and resource utilization will also be compared between the two models.
\end{abstract}

Discussion: The study in progress will assess whether a functional and highly trained home care team will meet the ever-aging population needs in terms of cost and health outcomes better than a traditional, integrated one. Lessons learned from this pilot study will provide guidelines for a future model of home care based on the IHI Triple Aim: better care, better health, and lower costs.

Trial registration: Registered in ClinicalTrials.gov (Identifier: NCT03461315; March 12, 2018).

Keywords: Home care models, Preventive home visits, Primary care, Geriatric assessment

\footnotetext{
* Correspondence: sebastia.santaeugenia@gencat.cat

${ }^{5}$ Chronic Care Program, Ministry of Health, Barcelona, Catalonia, Spain

${ }^{6}$ Central Catalonia Chronicity Research Group (C3RG), Centre for Health and

Societal Care Research (CESS), University of Vic - Central University of

Catalonia (UVIC-UCC), C. Miquel Martí i Pol, 1, 08500 Vic, Spain

Full list of author information is available at the end of the article
}

(c) The Author(s). 2020 Open Access This article is licensed under a Creative Commons Attribution 4.0 International License, which permits use, sharing, adaptation, distribution and reproduction in any medium or format, as long as you give appropriate credit to the original author(s) and the source, provide a link to the Creative Commons licence, and indicate if changes were made. The images or other third party material in this article are included in the article's Creative Commons licence, unless indicated otherwise in a credit line to the material. If material is not included in the article's Creative Commons licence and your intended use is not permitted by statutory regulation or exceeds the permitted use, you will need to obtain permission directly from the copyright holder. To view a copy of this licence, visit http://creativecommons.org/licenses/by/4.0/ The Creative Commons Public Domain Dedication waiver (http://creativecommons.org/publicdomain/zero/1.0/) applies to the data made available in this article, unless otherwise stated in a credit line to the data. 


\section{Background}

The increasing life expectancy in industrialized countries correlates with a rising prevalence of chronicity, disability, and dependence, thus stressing the need for healthcare services to make progress $[1,2]$. In Spain, multimorbid patients managed in a primary care setting account for $1.38 \%$ of the overall population and $5 \%$ of people older than 65 years old [3]. The increasing trend of these percentages will result in a greater use of health care resources, including medical appointments, visits to the emergency service, hospitalization, and medication [1-4]. Therefore, it is necessary to find cost-effective strategies to cover the healthcare needs of older patients.

In the last decade, various approaches to care delivery for older people have been proposed, yielding a repertoire of models that range from traditional primary care and total patient models to integrated care models [5-7]. As part of the services offered, home care $(\mathrm{HC})$ programs are intended to provide health care to patients that are unable to go to a primary care center due to their medical condition or disability, thus improving their health and active independence and reducing hospitalizations [8-11]. Some of these $\mathrm{HC}$ programs prioritize continuity in the sense that the same medical professional team (i.e., physician and nurse) attends the patient both at home and at the primary care center. This model, often referred to as integrated $\mathrm{HC}$, has the advantage of strengthening the relationship between patients and their healthcare provider but struggles with the staff's overloaded schedule [12, 13]. Other extensively applied models are based on skilled HC teams dedicated solely to athome interventions; this approach, known as functional $\mathrm{HC}$, increases specialization of the $\mathrm{HC}$ team and reduces the overburden of health care professionals, but may hamper the cohesion of healthcare services [14-16]. These models were implemented with positive outcomes regarding patients' quality of life and care delivery satisfaction. However, studies investigating the outcome of $\mathrm{HC}$ have yielded heterogenous results, which likely depend on multiple factors including population factors, program characteristics, and healthcare setting [15-17]. In fact, even healthcare environments were $\mathrm{HC}$ is well established as a reality for care of older and disabled people acknowledge that more in-depth analysis is needed to improve understanding of the role of $\mathrm{HC}$ in the future of health care delivery [18]. Taken together, this heterogeneity precludes the appraisal of the benefits and drawbacks of $\mathrm{HC}$ approach, often leading to inconclusive evidence [19].

Catalonia is the most north-eastern region of Spain, with a population of over 7.5 million people, $19 \%$ of which is older than 65 years. Here, $\mathrm{HC}$ programs are highly implemented, with nearly $90 \%$ of primary care units using traditionally integrated $\mathrm{HC}$ approaches within each provision of healthcare service, that enroll a $5 \%$ of the population older than 65 years. However, a survey of primary care professionals involved in $\mathrm{HC}$ programs revealed important disadvantages of this model, such as a high burden of care, time constraints, low resources and lack of coordination with other levels of care as each of the services provides $\mathrm{HC}$ assistance besides their center-based duties [20]. The change from a traditional integrated $\mathrm{HC}$ model to a functional full-time $\mathrm{HC}$ is expected to result in better outcomes for patients (clinical and related to the attendance experience), increased satisfaction for the professionals involved, and less use of healthcare resources. However, there is little or no evidence regarding the benefits and drawbacks of the two models when operating in the same healthcare environment. This study aims to compare two HC programs for older people applied in Catalonia: a traditional integrated $\mathrm{HC}$ model provided by healthcare professionals of primary care units and a specific full-time unit of medical professionals based on a functional $\mathrm{HC}$ model.

\section{Methods \\ Study design}

This quasi-experimental study will compare the outcome of two $\mathrm{HC}$ models implemented in two primary care centers in Badalona (Barcelona, Spain). The control group will consist of patients following the integrated HC model, provided by the primary care center Gran Sol, and the study group will consist of patients following the new $\mathrm{HC}$ model (hereinafter, functional $\mathrm{HC}$ model), linked to the primary care center Apenins. Both $\mathrm{HC}$ teams consist of a general practitioner and a nurse. In the integrated model, $\mathrm{HC}$ is given by the same healthcare team providing medical care at the primary care unit with an average of 1500 inhabitants assigned to each team. By contrast, in the functional model, $\mathrm{HC}$ is given by a healthcare team specifically trained in the management of older, frail and multimorbid patients, providing only full-time preventive home visits and connecting to other further required special provision services. Further details regarding the characteristics of each model are shown in Table 1. The rationale for choosing these two centers relates to the balanced demographic characteristics of the reference population (Table 2).

After signing the consent form to participate in the study during a preventive home visit, patients (or their caregivers) are provided with a set of self-administered questionnaires and scales, as well as a return envelope. In the case of patients with cognitive impairment, the 
Table 1 Main characteristics of the two investigated models

\begin{tabular}{|c|c|c|}
\hline \multicolumn{2}{|c|}{ Integrated HC } & \multirow[t]{2}{*}{ Functional HC } \\
\hline Characteristics of the healt & thcare team & \\
\hline Team composition & Nurse and family doctor. & \\
\hline Team function & $\begin{array}{l}\text { The same healthcare team provides } \mathrm{HC} \text { and manages } \\
\text { patients in the primary care center. }\end{array}$ & The healthcare team is dedicated exclusively to HC. \\
\hline $\begin{array}{l}\text { Interprofessional } \\
\text { communication }\end{array}$ & $\begin{array}{l}\text { Healthcare professionals are part of the healthcare team } \\
\text { regularly managing patients in the primary care center. }\end{array}$ & $\begin{array}{l}\text { Although not managing patients in the primary care center, the } \\
\mathrm{HC} \text { team is part of the health care staff of the center and their } \\
\text { members participate in the center meetings as specialists. }\end{array}$ \\
\hline Training & $\begin{array}{l}\text { - Regular training of family doctors, including regular } \\
\text { stays at mental health and geriatrics units. } \\
\text { - Regular training of nurses. }\end{array}$ & $\begin{array}{l}\text { - Regular training of family doctors, including regular stays at } \\
\text { mental health and geriatrics units. } \\
\text { - Nursing staff receives additional training regarding the } \\
\text { management of chronic patients, fragility, and palliative care. }\end{array}$ \\
\hline $\begin{array}{l}\text { Type of professional } \\
\text { in each visit }\end{array}$ & Nurse, family doctor or both & \\
\hline \multicolumn{3}{|l|}{ Services and visit schedule } \\
\hline Preventive visits & $\begin{array}{l}\text { - Visits of nursing staff scheduled based on the monitorin } \\
\text { - Visits of physician scheduled at physician's discretion bas }\end{array}$ & $\begin{array}{l}\text { g requirements of each disease as established by local guidelines. } \\
\text { ed on the disease progression and clinical status of patients. }\end{array}$ \\
\hline $\begin{array}{l}\text { Non-urgent acute } \\
\text { visits }\end{array}$ & $\begin{array}{l}\text { The patient calls the center and the physician available } \\
\text { at that moment (not always the one regularly visiting } \\
\text { the patient at the primary care center) visits the } \\
\text { patient at home. }\end{array}$ & $\begin{array}{l}\text { - During working hours: the patient contacts directly the } \\
\text { physician of the } \mathrm{HC} \text { team. } \\
\text { - Outside the working hours: the patient calls the center and } \\
\text { the physician available at that moment (not always the one } \\
\text { regularly visiting the patient at the primary care center) visits } \\
\text { the patient at home. }\end{array}$ \\
\hline Urgent visits & \multicolumn{2}{|c|}{ The patient calls the emergency service; an emergency team and an ambulance are deployed to patient's home. } \\
\hline Financial approach & \multicolumn{2}{|l|}{ All visits are fully covered by the public health system. } \\
\hline
\end{tabular}

HC home care

documents are delivered to the caregiver. Investigators will contact study patients by phone every 6 months and ask them about their admissions to other centers than the assigned primary care center. At the end of followup (i.e., 2 years), study patients (or their caregivers) will be provided with the same self-administered questionnaires and scales given at baseline in a final preventive home visit (Fig. 1). Clinical and demographic data will be retrieved from patients' medical records. All the information retrieved from the three sources (i.e., questionnaires/scales, check-up phone calls, and medical records) will be recorded in a clinical report form specifically designed for the study. Before the baseline visit, all investigators will participate in two training sessions on the scales and questionnaires used in the study.

All the $\mathrm{HC}$ interventions performed on both $\mathrm{HC}$ programs are based on current protocols designed following recommendations of the semFYC (Spanish Society of

Table 2 Characteristics of the participating centers

\begin{tabular}{lll}
\hline & $\begin{array}{l}\text { Integrated HC } \\
\text { (PC Gran Sol) }\end{array}$ & $\begin{array}{l}\text { Functional HC } \\
\text { (PC Apenins) }\end{array}$ \\
\hline $\begin{array}{l}\text { Location } \\
\text { Professional profile }\end{array}$ & Badalona, Catalonia, Spain & Badalona, Catalonia, Spain \\
Reference population ${ }^{\text {b }}$, No. & 19,442 & MDs and nurses specialized in family medicine \\
Over-Aging index,$\%$ & $11 \%$ & 19,043 \\
Foreign population ${ }^{\mathrm{d}}, n$ (\%) & $3499(17.9 \%)$ & $9.2 \%$ \\
$\geq 65$ years old, $n(\%)$ & $3480(17.9 \%)$ & $3046(15.9 \%)$ \\
GMA, adjusted indicator (IC95\%) & $1.189(1.173-1.206)$ & $2970(15.6 \%)$ \\
Mortality, annual \%o & 7 & $1.178(1.161-1.195)$ \\
IT application & eCAP & 0.001 \\
\hline
\end{tabular}

HC Home Care, GMA Adjusted Morbidity Groups [21]; IT Information Technology, MD Medical Doctor, PC Primary Care ${ }^{a}$ Differences between PC Gran Sol and PC Apenins

${ }^{b}$ Data from Msiq (Generalitat de Catalunya@), period between January and December 2015

'The number of persons aged 74 or over per total of persons over 64 years old

${ }^{\mathrm{d}}$ The number of subjects with a foreign nationality 


\section{Timeline}

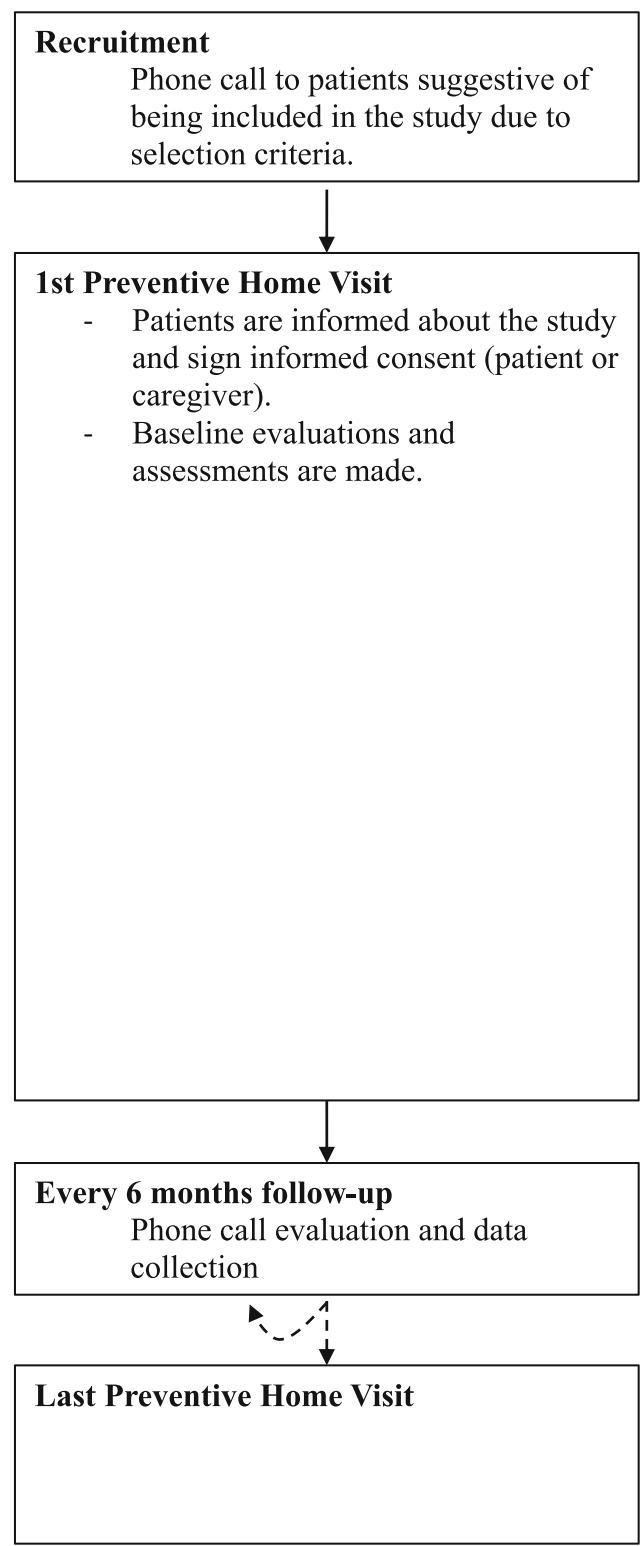

Assessments

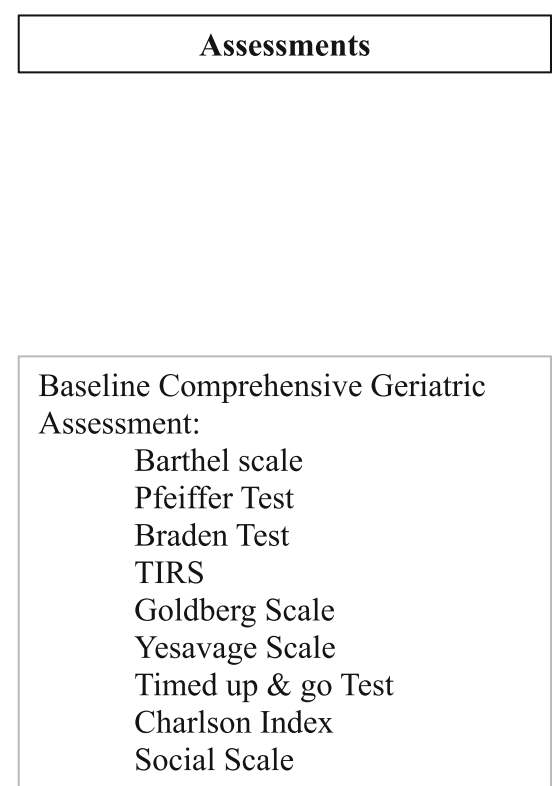

Baseline evaluation of:

Home Adequacy

Falls

Frailty (Gerontopole)

Self-administered scales:

EuroQOL

IEXPAC

Zarit (caregiver, if needed)

Evaluation of:

Resources consumption

Private resources use

Self-administered scales:

EuroQOL

IEXPAC

Zarit (caregiver)

Fig. 1 Flowchart of interventions to patients during the study

Family and Community medicine) and EUROPREV (European Network for Prevention and Health Promotion in Family Medicine and General Practice) inside the Program of preventive activities for Health promotion (PAPPS) [22]. The study protocol was approved by the IDIAP Ethics Committee of the Jordi Gol Foundation (Approval code: P17/121). Patients will volunteer and sign an informed consent, and all the information gathered will be anonymized before conducting any analysis. All data will be handled according to the Spanish Data
Protection Law (LOPD) 15/1999 and the EU General Data Protection Regulation 2016/679.Considering the routine interventions defined in the study, conventional risks are not expected to increase. The last visit of the last patient recruited is foreseen by October 2020.

\section{Selection criteria}

All patients aged over 65 years old and enrolled in the long-term $\mathrm{HC}$ program at any of the two participating primary care centers for at least 3 months will be 
considered for eligibility. Patients will be included irrespective of their cognitive status. Exclusion criteria include patients with a life expectancy of less than a month and patients with a score of 5 or more in the Pfeiffer's test that does not have a full-time caregiver or that have a part-time one because a severe cognitive impairment is likely to interfere with the study procedure. Patients that are not registered as Badalona citizens will also be excluded because it is assumed they have temporary status, as well as patients included in a $\mathrm{HC}$ program due to their reduced mobility to reduce bias when measuring patient-requested interventions because they cannot easily reach the primary care center facility.

\section{Patient recruitment}

Between June and October 2018, all subjects included in the $\mathrm{HC}$ program at the two primary care centers that met the selection criteria were contacted by phone and offered to participate in the study. Patients willing to do so were scheduled a domiciliary visit to receive the study documents (i.e., the Patient Information Sheet and selfadministered questionnaires/scales) and sign the informed consent themselves or, in case of cognitive impairment, their full-time caregivers.

\section{Study conduct}

The study started in June 2018 and is expected to end by October 2020. On the first preventive home visit, once informed consents have been accepted, patients, or the caregivers in case of cognitive impairment (defined as subjects scoring 5 or more in the Pfeiffer's test), will be given self-administered questionnaires like EuroQoL, IEXPAC, and Zarit [23-25]. All of them will be analyzed by the investigator, who will assess the patient's frailty in situ. The self- administered scales will be completed again by the patient and/or caregiver 2 years later, in a preventive home visit at the end of the study. Besides this start and end visits, participants will be interviewed by phone every 6 months to solve any issues and find out if any private hospitalizations or daycare centers have been used. Also, all visits requested by either the patient or the reference doctor will be reported in a case report form (CRF). The medical professionals involved in the study performing the preventive home visits will be trained for the study and in the use of the scales to ensure consistency and reinforce their implication.

All data, irrespective of their source, will be recorded in an anonymized CRF, in which patients will be identified with a study code. The study investigator will keep a key table with the study codes and their corresponding medical record identification codes.

\section{Endpoints and variables}

The primary endpoint will be the difference in mean days of hospital stay per year between patients included in the integrated and functional HC programs. Secondary endpoints will include the assessment of the differences between the two $\mathrm{HC}$ models i.e., mortality and hospital admissions, based on the IHI Triple Aim (Better Care, Better Health, Lower Costs) [26]. To this end, variables regarding subjects' health status, quality of care, and resource utilization of patients included in the two models will be compared (Table 3). The demographic characteristics of the study participants will also be recorded.

Particularly, the baseline health status of study subjects will include the Gerontôpole frailty screening tool and the Adjusted Morbidity Groups (GMA) risk assessment tool, which considers the type of disease, number of systems affected, and complexity of each one [21,37]. Additionally, a complete baseline Comprehensive Geriatric Assessment (CGA) will be performed, including the following assessments: the ability to perform normal daily tasks (Barthel scale), mental health status (Pfeiffer test), decubitus ulceration risk (Braden test), social risk (TRIS), geriatric depression (Yesavage scale), mobility status (Timed up \& go test), comorbidity burden (Charlson Comorbidity Index), nutritional state (Mini-nutritional Assessment), and social status (Table 3) [27-35, 41]. The health-related quality of life of study participants and satisfaction of caregiver will be assessed at baseline and at the final follow-up visit using the EuroQoL IEXPAC and Zarit questionnaires, respectively [23-25].

\section{Statistical analysis}

The sample size calculation was based on an incidence of hospital admission of $40 \%$ and a reduction of $10 \%$ in the study group, a 2-year follow-up, and a 1:1 ratio for control and intervention groups. Under these constrains, a fixed alpha and beta errors of 5\%, yielded an estimated size of 581 subjects per group. The statistical power of this sample, assuming alpha and beta errors of $5 \%$ was $85.3 \%$.

All collected variables will be described for the overall study sample and for both study groups. Quantitative variables will be described as the mean and standard deviation (SD), and as the median and interquartile range (IR) for normally- and non-normally distributed variables, as confirmed by the Kolmogorov-Smirnov test. Categorical variables will be described as frequencies and percentages. Measures of central tendency will be compared using the T-test for independent samples or ANOVA, or their non-parametric counterparts: the Mann-Whitney U and Kruskal-Wallis tests. Categorical variables will be compared using the Chi-square test or 
Table 3 Study variables

\begin{tabular}{|c|c|c|}
\hline & Definition and Measurements & Categories \\
\hline \multicolumn{3}{|c|}{ Demographic Characteristics } \\
\hline Age & At the moment of entering the $\mathrm{HC}$ program & $\begin{array}{l}65-74 \\
75-84 \\
>85\end{array}$ \\
\hline Gender & & Male | Female \\
\hline \multicolumn{3}{|l|}{ Health Status } \\
\hline Caregiver & At the time of entering the $\mathrm{HC}$ program & Yes | No \\
\hline Level of dependency & $\begin{array}{l}\text { Scale defined by Royal Decree 174/2011; Law 39/2006 of Promotion of } \\
\text { Personal Autonomy and Care for People in Situations of Dependency. }\end{array}$ & $\begin{array}{l}\text { Grade I (25-49): Moderate dependency } \\
\text { Grade II (50-74): Severe dependency } \\
\text { Grade III (75-100): Great dependency }\end{array}$ \\
\hline Decubitus ulcer & At physician's discretion & Presence | absence \\
\hline Drugs prescribed & By active substance. & $\begin{array}{l}\text { Not polymedicated }(<5) \\
\text { Polymedicated }(5-10) \\
\text { Hyperpolymedicated }(>10)\end{array}$ \\
\hline Comorbidity burden & $\begin{array}{l}\text { Measured by Adjusted Morbidity Groups (GMA) risk assessment tool. GMA } \\
\text { considers the type of disease (i.e. acute or chronic), number of systems } \\
\text { affected, and complexity of each disease, which is coded by the International } \\
\text { Classification of Diseases (ICD-9-CM) and stratify depending on the complexity. }\end{array}$ & 31 qualitative ordinal GMA levels. \\
\hline Mortality & Death during follow-up & Yes | No \\
\hline Realization of CGA & & Yes | No \\
\hline
\end{tabular}

Assessments included in CGA

Performance of normal Barthel Scale [27] daily tasks

Mental health

Pfeiffer's Test [28]

Decubitus ulceration Braden Test [29]

risk

Social risk

TIRS [30]

Anxiety

Goldberg Scale [31]

Geriatric depression

scale

Mobility

Comorbidity

Social state

Overburden of the caregiver

Nutritional state evaluation
Charlson Index [34]

Social Scale [35]

Yesavage Scale [32]

Timed Up and Go Test [33]

Zarit Test [25]

MNA [36]
Total dependency $(<20)$

Severe dependency (20-60)

Moderate dependency (61-90)

Mild dependency (91-99)

Autonomous (100)

High risk ( $\leq 2)$

Mild cognitive impairment (3-4)

Moderate cognitive impairment (5-7)

Severe cognitive impairment

High risk $(<12)$

Moderate risk (13-14)

Low risk (15-18)

There is social risk when one indicator over 6 is positive

Probable anxiety ( $\geq 4$ positive responses) Probable depression ( $\geq 2$ positive responses)

No depression (1)

Possible depression $(\geq 2)$

Normal $(<10)$

Very little impaired (10-19)

Moderately impaired (20-29)

Severely impaired $(\geq 30)$

No comorbidity (0-1)

Low comorbidity burden (2) High comorbidity burden $(>3)$

No social risk $(\leq 9)$

Social risk (10-14)

Social problem $(\geq 15)$

No overburden $(<46)$

Intense overburden (> 56)

Malnutrition ( $\leq 7)$

Malnutrition risk (8-11)

Normal nutritional status $(\geq 12)$ 
Table 3 Study variables (Continued)

\begin{tabular}{|c|c|c|}
\hline & Definition and Measurements & Categories \\
\hline Home adequacy & $\begin{array}{l}\text { Revision of home adequacy to determine the need of social } \\
\text { worker intervention }\end{array}$ & $\begin{array}{l}\text { Social worker is recommended when at } \\
\text { least one item is positive }\end{array}$ \\
\hline Falls & Number of falls in the last year & - \\
\hline Frailty & Gérontopôle Frailty Screening Tool [37] & $\begin{array}{l}\text { Frailty identification if one item of the } \\
\text { scale is positive. }\end{array}$ \\
\hline Social services cost & Number and cost of social worker visits & - \\
\hline Quality of life & EuroQOL 5D-3 L $[24,38,39]$ & $\begin{array}{l}\text { No problems (Level 1) } \\
\text { Some problems (Level 2) } \\
\text { Extreme problems (Level 3) }\end{array}$ \\
\hline \multicolumn{3}{|l|}{ Quality of Care } \\
\hline Physicians PQI & Prescription Quality Index of the physician [40] & $\begin{array}{l}\text { Include assessment of three categories: } \\
\text { More adequate therapeutic alternatives } \\
\text { Hyper prescription of a particular group } \\
\text { of drugs } \\
\text { Selection indicators to promote safer } \\
\text { and more effective alternatives available }\end{array}$ \\
\hline Prescriptions & Number of prescription events per patient & - \\
\hline $\begin{array}{l}\text { Alternative drugs with } \\
\text { therapeutic benefit }\end{array}$ & Percentage of use of the alternative drug as assessed by the physician & - \\
\hline $\begin{array}{l}\text { Shared Interdisciplinary } \\
\text { Individual plan }\end{array}$ & & Yes | No \\
\hline Chronicity & $\begin{array}{l}\text { Number of Complex Chronic Patients and Advanced Chronic Disease } \\
\text { patients in the program }\end{array}$ & - \\
\hline $\begin{array}{l}\text { Satisfaction with health } \\
\text { care received }\end{array}$ & IEXPAC Scale [23] & $\begin{array}{l}\text { Satisfactory }(=10) \\
\text { Unsatisfactory }(<10)\end{array}$ \\
\hline $\begin{array}{l}\text { Overburden of the } \\
\text { caregiver }\end{array}$ & Zarit Scale [25] & $\begin{array}{l}\text { No overburden }(<46) \\
\text { Intense overburden }(>56)\end{array}$ \\
\hline \multicolumn{3}{|l|}{ Resource Utilization } \\
\hline Family doctor visits & $\begin{array}{l}\text { Number of at-home visits, other medical professional, primary care center or } \\
\text { virtual appointments of the patient or the caregiver }\end{array}$ & - \\
\hline Nursing staff visits & $\begin{array}{l}\text { Number of at-home visits, other medical professional and primary care center } \\
\text { appointments of the patient or the caregiver. Also, number of virtual } \\
\text { consultations, including remote evaluation or by phone of medical record }\end{array}$ & - \\
\hline Hospitalizations & Number of programmed, emergency and daycare admissions & - \\
\hline Readmissions & $\begin{array}{l}\text { Number of successive hospitalizations due to the same pathology in } \\
\text { less than } 30 \text { days }\end{array}$ & - \\
\hline $\begin{array}{l}\text { Admissions to other } \\
\text { public health care } \\
\text { centers }\end{array}$ & $\begin{array}{l}\text { Number of admissions, including convalescence, subacute, long-lasting and } \\
\text { palliative units }\end{array}$ & - \\
\hline $\begin{array}{l}\text { Hospitalizations per } \\
\text { year }\end{array}$ & Days hospitalized & - \\
\hline Intermediate resources & Number and cost of laboratory tests, Radiology and interconsultations & - \\
\hline Pharmaceutical costs & Expenditure per patient and medical professional during a year & - \\
\hline $\begin{array}{l}\text { Hospitalization-at- } \\
\text { home device use }\end{array}$ & Number of activations per year and total of hospitalization days & - \\
\hline Social services intensity & $\begin{array}{l}\text { Monthly hours spent by the social worker. Costs derived from teleassistance, } \\
\text { cleaning and cooking aid, reused orthopedic material and family worker }\end{array}$ & - \\
\hline $\begin{array}{l}\text { Call to emergency } \\
\text { services }\end{array}$ & Number of patient intervention requests per year. & - \\
\hline $\begin{array}{l}\text { Perception of } \\
\text { healthcare } \\
\text { professionals }\end{array}$ & $\begin{array}{l}\text { Qualitative, self-administered questionnaire of difficulties in } \mathrm{HC} \text { practice, based } \\
\text { on the survey reported by Linares et al. [20] }\end{array}$ & \\
\hline
\end{tabular}


Fisher's exact test. If post hoc analyses are performed, the Bonferroni or the Games-Howell adjustments will be applied. Variables with differences in the bivariate analysis at baseline $(p<0.1)$ and those considered clinically relevant for the authors will be included in a linear multiple logistic regression to build a multivariate model to predict the difference in mean days of hospital stay and costs of patients in the HC program. To address Better Care and Better Health endpoints, the authors will apply a binary logistic regression for mortality and hospital admission variables; age, gender, and comorbidity burden will be included as adjustment variables. A backward stepwise regression will be used to avoid overfitting of the model obtained.

A significance threshold will be set at two-sided alpha value $<0.05$. The analysis will be performed with SPSS (IBM Corp. Released 2012. IBM SPSS Statistics for Windows, Version 21.0. Armonk, NY: IBM Corp.).

\section{Discussion}

Since life expectancy of the population is increasing in developed countries, healthcare policymakers are prompted to tailor healthcare services to the specific needs of older people. In this context, the local healthcare authorities in Badalona (Spain) decided to change from a integrated $\mathrm{HC}$ model to a functional $\mathrm{HC}$ model, in which preventive home visits are provided by a dedicated healthcare team, different from that looking after patients in primary care units. Although various models of functional care have been proposed to prevent unnecessary hospitalizations and contribute to better health outcomes in post-acute patients $[15,16,42]$, different populations and healthcare settings make it necessary to assess the outcome of this change in our area.

The main strengths of the functional model include a faster response to emergencies and the specialization of healthcare professionals. On the other hand, a potential disadvantage of this model -compared with the integrated one- is that it breaks the continuity of care (i.e., the patient is attended by a different healthcare team in the primary care unit and at home). Despite this limitation, the functional model is expected to yield better outcomes. In addition to the comparative analysis between both models, previous experiences in similar populations from our area will serve as a reference to interpret the results obtained $[43,44]$.

An important strength of this study is the homogeneity of both study groups. The quasi-experimental design precludes an active selection of the study sample, which is naturally defined by patients attending one of the primary care units based on their location. However, the characteristics of the reference population of both centers are very similar in terms of age and complexity (measured using the GMA risk [21, 45, 46]), suggesting that the baseline characteristics of study patients are likely to be balanced at the end of the study. Furthermore, unlike other change assessments in the HC model, this study will capture data prospectively, thus favoring the accuracy of the final record.

On the other hand, some limitations can be predicted. Firstly, a possible Hawthorne effect, according to which the quality of care may improve due to the fact that healthcare professionals are being assessed [47] cannot be ruled out. To our understanding, this effect -in case it occurs- is likely to decline throughout follow-up. Secondly, it seems almost unavoidable that patients will fail to report the use of private facilities, a fact that shall be considered at the moment of reporting results. Finally, this study has a risk of unbalanced reporting bias due to the differences in the healthcare teams of each model. Specifically, whereas in the integrated $\mathrm{HC}$ group multiple observers will contribute to data capture, in the functional group all assessments will be performed by a single $\mathrm{HC}$ team. In this regard, the reporting bias is likely to be attenuated in the integrated group by the presence of multiple observers, but not in the functional group. To increase homogeneity in practices and data recording, all investigators will receive a brief training.

In summary, the proposed study will permit assessment of health outcomes, feasibility, and resource utilization of new functional $\mathrm{HC}$ model and identify its strengths and weaknesses compared to the integrated model. The results obtained from this study may have important policy implications.

\section{Abbreviations}

CGA: Comprehensive Geriatric Assessment; CRF: Case Report Form; GMA: Adjusted Morbidity Group; HC: Home Care; IEXPAC: Instrument to Evaluate the Experience of Patients with Chronic Diseases; IR: Interquartile Range; IT: Information Technology; MD: Medical Doctor; MNA: Mini Nutritional Assessment; PC: Primary Care; PQI: Prescription Quality Index; SD: Standard Deviation; TIRS: Test Indicators of Social Risk

\section{Acknowledgements}

The authors would like to thank i2e3 Biomedical Research Institute for providing medical writing assistance, and the EuroQol Research Foundation for kindly providing the 5D $3 \mathrm{~L}$ EuroQoL questionnaire.

\section{Authors' contributions}

Research idea and study design: CB, SS, JCC; implementation of the design: $\mathrm{CB}, \mathrm{RS}, \mathrm{SS}$; evaluation of measures: CB, RS, SS, FT; statistical considerations: FT; supervision or mentorship: CB, SS, MM. Each author contributed important intellectual content during manuscript drafting or revision and accepts accountability for the overall work by ensuring that questions pertaining to the accuracy or integrity of any portion of the work are appropriately investigated and resolved. The authors read and approved the final manuscript.

\section{Funding}

No additional funding was required in the development of the current study.

\section{Availability of data and materials}

Data sharing is not applicable to this article as no datasets were generated or analyzed during the development of this protocol. All data generated or analyzed during this study are included in this published article and its supplementary information file. 


\section{Ethics approval and consent to participate}

The study protocol was approved by the IDIAP Ethics Committee of the Jordi Gol Foundation (Approval code: P17/121). Approved informed consent was signed by all patients or caregivers, before their inclusion. In case of cognitive impairment (i.e., a score of 5 or more in Pfeiffer's test) only caregivers will be asked to sign under the statement: "I, [name of caregiver participant], have read the Information Sheet for the study in which my dependent is asked to participate. My questions, if any, have been answered to my satisfaction. Therefore, I consent to participate in the study."

\section{Consent for publication}

Not applicable.

\section{Competing interests}

The authors declare that they have no competing interests.

\section{Author details}

${ }^{1}$ Department of Surgery and Surgical Specializations, Faculty of Medicine, University of Barcelona (PC 08036), Barcelona, Catalonia, Spain. ${ }^{2}$ Primary Care Center Apenins, Badalona Serveis Assistencials, Badalona, Catalonia, Spain. ${ }^{3}$ Primary Care Center Gran Sol, Institut Català de la Salut, Badalona, Catalonia, Spain. ${ }^{4}$ Geriatric Medicine Department, Hospital Universitario de la Ribera, Alzira, Valencia, Spain. ${ }^{5}$ Chronic Care Program, Ministry of Health, Barcelona, Catalonia, Spain. ${ }^{6}$ Central Catalonia Chronicity Research Group (C3RG), Centre for Health and Societal Care Research (CESS), University of Vic - Central University of Catalonia (UVIC-UCC), C. Miquel Martí i Pol, 1, 08500 Vic, Spain.

Received: 24 January 2019 Accepted: 27 February 2020

Published online: 12 March 2020

\section{References}

1. Wolff $\lrcorner$, Starfield B, Anderson G. Prevalence, expenditures, and complciations of multiple chronic conditions in the elderly. Arch Intern Med. 2012;162(20):2269-76

2. Mitnitski $A B$, Rutenberg $A D$, Farrell $S$, Rockwood K. Aging, frailty and complex networks. Biogerontology. 2017;18(4):433-46.

3. Ministerio de Sanidad y Política Social. Unidad de Pacientes Pluripatológicos. Estándares y Recomendaciones. [Internet]. 2009. Available from: https://www.mscbs.gob.es/organizacion/sns/planCalidadSNS/docs/ EyR_UPP.pdf. [cited 3 Mar 2020].

4. Gené Badia J, Borràs Santos A, Contel Segura JC, Ascaso Terén C, González Ortega M, Gallo De Puelles P. Factors associated with hospitalization in a cohort of elderly patients included in a home care program. Med Clin (Barc). 2012;139(11):473-8.

5. Have W, Learned W, Lookinland S. Traditional models of care delivery: what have we learned? J Nurs Adm. 2004;34(6):291-7.

6. World Health Organization. Integrated care models: an overview. [Internet] 2016. Available from: http://www.euro.who.int/ data/assets/pdf file/ 0005/322475/Integrated-care-models-overview.pdf. [cited 3 Mar 2020].

7. Kodner DL, Spreeuwenberg C. Integrated care: meaning, logic, applications, and implications--a discussion paper. Int J Integr Care. 2002;2:e12.

8. Stuck AE, Egger M, Hammer A, Minder CE, Beck CJ. Home visits to prevent nursing home admission and functional decline in elderly people: systematic review and meta-regression analysis. JAMA. 2002;287(8):1022-8.

9. Caplan GA, Williams AJ, Daly B, Abraham K. A randomized, controlled trial of comprehensive geriatric assessment and multidisciplinary intervention after discharge of elderly from the emergency department--The DEED II Study. J Am Geriatr Soc. 2004;52:1417-23.

10. Dainty KN, Golden BR, Hannam R, Webster F, Browne G, Mittmann N, et al. A realist evaluation of value-based care delivery in home care: the influence of actors, autonomy and accountability. Soc Sci Med. 2018;206:100-9.

11. Mogensen CB, Ankersen ES, Lindberg MJ, Hansen SL, Solgaard J, Therkildsen $P$, et al. Admission rates in a general practitioner-based versus a hospital specialist based, hospital-at-home model: ACCESS, an open-labelled randomised clinical trial of effectiveness. Scand J Trauma Resusc Emerg Med. 2018;26(1):26

12. Low LL-F, Yap M, Brodaty $H$. A systematic review of different models of home and community care services for older persons. BMC Health Serv Res. 2011;11(1):93.

13. Booker C, Turbutt A, Fox R. Model of care for a changing healthcare system: are there foundational pillars for design? Aust Health Rev. 2016;40(2):136-40.
14. Watts SA, Lucatorto M. A review of recent literature - Nurse case managers in diabetes care: Equivalent or better outcomes compared to primary care providers. Curr Diab Rep. 2014;14(7):504.

15. Lo $\mathrm{C}$ et al. An australian model of care for co-morbid diabetes and chronic kidney disease. 2018.

16. Hoff T, Weller W, DePuccio M. The patient-centered medical home. Med Care Res Rev. 2012;69(6):619-44. https://doi.org/10.1177/1077558712447688.

17. Huss A, Stuck AE, Rubenstein LZ, Egger M, Clough-Gorr KM. Multidimensional preventive home visit programs for community-dwelling older adults: A systematic review and meta-analysis of randomized controlled trials. J Gerontol A Biol Sci Med Sci. 2008;63(3):298-307. [cited 2019 Sep 6]. https://doi.org/10.1093/gerona/63.3.298.

18. The Alliance for Home Health Quality \& Innovation. The future of home health care project. 2014. Available from: http://www.ahhqi.org/images/pdf/ future-whitepaper.pdf.

19. Tourigny A, Bédard A, Laurin D, Kröger E, Durand P, Bonin L, et al. Preventive home visits for older people: a systematic review. Can J Aging. 2015:34(4):506-23.

20. Aóiz Linares Jl, Aranzana Martínez A, Babi Rourera P, Muñoz Muñoz RB, Castellá Dagà I, Cegri Lombardo F, et al. Aproximación a la atención domiciliaria. ¿Cómo trabaja la sanidad pública catalana la atención domiciliaria? Aten Primaria. 2003:31(8):473-7.

21. Monterde D, Vela E, Clèries M, García Eroles L, Pérez Sust P. Validez de los grupos de morbilidad ajustados respecto a los clinical risk groups en el ámbito de la atención primaria. Atención Primaria. 2018;51:153-61.

22. Sociedad Española de Medicina de Familia y Comunitaria. Atencion primaria. Aten Primaria. 2018:50(S1):1-152

23. Mira JJ, Nuño-Solinís R, Guilabert-Mora M, Solas-Gaspar O, Fernández-Cano P, González-Mestre MA, et al. Development and validation of an instrument for assessing patient experience of chronic illness care. Int J Integr Care. 2016;16(3):1-13.

24. Group E. EuroQol - a new facility for the measurement of health-related quality of life. Health Policy. 1990;16(3):199-208.

25. Zarit SH, Reever KE, Bach-Peterson J. Relatives of the impaired elderly: correlates of feeling of burden. Gerontologist. 1980;20(6):649-55.

26. $10 \mathrm{IHI}$ Innovations to Improve Health and Health Care. Cambridge, Massachusetts: Institute for Healthcare Improvement; 2017. Available at: https://www.ihi.org.

27. Fi M, Dw B. Functional evaluation: The barthel index. Md State Med J. 1965; 14:56-61.

28. Pfeiffer E. A short portable mental status questionnaire for the assessment of organic brain deficit in elderly patients. J Am Geriatr Soc. 1975;23(10):433-41.

29. Braden B, Bergstrom N. A conceptual schema for the study of the etiology of pressure sores. Rehabil Nurs. 1987;12(1):8-12.

30. Institut Català de la Salut. El treball social sanitari en I'atenció al pacient crònic. [Internet]. 2013. Available from: https://treballsocialsanitariics.files. wordpress.com/2015/11/el-treball-social-sanitari-en-latencic3b3-al-pacientcrc3b2nic-document-de-metodologia-deprocc3a9s-2013-ics.pdf. [cited 3 Mar 2020].

31. Goldberg D, Bridges K, Duncan-Jones P, Grayson D. Detecting anxiety and depression in general medical settings. BMJ. 1988;297(6653):897-9.

32. Yesavage JA, Sheikh J. 9/geriatric depression scale (GDS). Clin Gerontol. 1986;5(1-2):119-36.

33. Podsiadlo D, Richardson S. The timed "up \&amp; go": a test of basic functional mobility for frail elderly persons. J Am Geriatr Soc. 1991;39(2): 142-8. https://doi.org/10.1111/j.1532-5415.1991.tb01616x.

34. Charlson ME, Pompei $P$, Ales KL, Mackenzie CR. A new method of classifying prognostic comorbidity in longitudinal studies: development and validation. J Chronic Dis. 1987:40(5):373-83.

35. García J, Díaz E, Salamea A, Cabrera D, Menéndez A, Fernández A, et al. Evaluación de la fiabilidad y validez de una escala de valoración social en el anciano. Atención Primaria. 1999;23:434-40.

36. Guigoz Y, Vellas B, Garry P. Mini Nutritional Assessment: a practical assesment tool for grading the nutricional state of elderly patients. Facts Res Gerontol. 1994;12(supl 2):15-59.

37. Tavassoli N, Guyonnet S, Abellan Van Kan G, Sourdet S, Krams T, Soto ME, et al. Description of 1,108 older patients referred by their physician to the \&quot;geriatric frailty clinic (G.F.C) for assessment of frailty and prevention of disability\&quot; at the gerontopole. J Nutr Health Aging. 2014;18(5):457-64.

38. Greiner W, Weijnen T, Nieuwenhuizen M, Oppe S, Badia X, Busschbach J, et al. A single European currency for EQ-5D health states: results from a sixcountry study. Eur J Health Econ. 2003;4(3):222-31. 
39. EuroQoL Research Foundation. EQ-5D-3L User Guide. 2018. Available from: https://euroquol.org/publications/user-guides.

40. Departament de Salut. Índex de qualitat de la prescripció farmacèutica (IQF). Àrea Medicament; 2018.

41. Vellas B, Guigoz Y, Garry PJ, Nourhashemi F, Bennahum D, Lauque S, et al. The mini nutritional assessment (MNA) and its use in grading the nutritional state of elderly patients. Nutrition. 1999;15(2):116-22.

42. Hunt L. Why intermediate care services need to be refreshed. Nurs Older People. 2014;26(3):16-20.

43. Gené Badia J, Borràs Santos A, Contel Segura JC, Ascaso Terén C, González Ortega M, Gallo De Puelles P. Factores asociados a ingreso hospitalario en una cohorte de pacientes ancianos incorporados a un programa de atención domiciliaria. Med Clin (Barc). 2012;139(11):473-8.

44. Gene Badia J, Borras Santos A, Contel Segura JC, Teren CA, Gonzalez LC, Ramirez EL, et al. Predictors of mortality among elderly dependent home care patients. BMC Health Serv Res. 2013;13:316.

45. Cancio $\mathrm{JM}$, Vela $\mathrm{E}$, Santaeugènia $\mathrm{S}$, Clèries $\mathrm{M}$, Inzitari $\mathrm{M}$, Ruiz $\mathrm{D}$. Influence of demographic and clinical characteristics of elderly patients with a hip fracture on mortality: a retrospective, total cohort study in north-East Spain. Bone. 2018;117:123-9.

46. Cainzos-Achirica M, Rebordosa C, Vela E, Cleries M, Matsushita K, Plana E, et al. Challenges of evaluating chronic heart failure and acute heart failure events in research studies using large health care databases. Am Heart J. 2018:202:76-83.

47. Schnelle JF, Ouslander JG, Simmons SF. Direct observations of nursing home care quality: does care change when observed? J Am Med Dir Assoc. 2006;7(9):541-4.

\section{Publisher's Note}

Springer Nature remains neutral with regard to jurisdictional claims in published maps and institutional affiliations.

Ready to submit your research? Choose BMC and benefit from:

- fast, convenient online submission

- thorough peer review by experienced researchers in your field

- rapid publication on acceptance

- support for research data, including large and complex data types

- gold Open Access which fosters wider collaboration and increased citations

- maximum visibility for your research: over $100 \mathrm{M}$ website views per year

At BMC, research is always in progress.

Learn more biomedcentral.com/submissions 